\title{
Urban Forestry in Windsor, Ontario
}

\author{
W. A. G. Morsink and L. O. W. Burridge
}

Department of Parks and Recreation

Windsor, Ontario

\begin{abstract}
An urban forestry program in Windsor, Ontario, focuses on the planting and maintenance of a permanent canopy of street and park trees. Diversification of the tree population has resulted from an emphasis on the use of native tree species, together with various management techniques.
\end{abstract}

\section{Résumé}

1.- Un programme en foresterie urbaine institué par le département des Parcs, Windsor, Ontario, vise principalement sur la plantation et l'entretien d'un couvert constant d'arbres des parcs et des rues. La variété de la population arborescente provient en partie de l'utilisation des espèces autochtones, jumelée avec certaines techniques variées d'aménagement.

\section{Introduction}

Jorgensen (1974) indicated that, as large scale urbanization takes place, a need develops for a planned approach to urban vegetation management.

Windsor, for example, is comprised of seven smaller communities interspersed with remnant market gardens and abandoned farm lands. In 1935 Windsor was enlarged by the inclusion of the towns of Sandwich, Walkerville, and East Windsor. In 1966 the towns of Riverside, Ojibway, and parts of East, South and West Sandwich Townships were annexed, resulting in an increase in area of 4,000 ha to 13,200 ha.

The tree cover of these former towns was predominantly maple or elm, poorly managed and subject to disease and insect attack. Urban renewal, road and sewer construction, together with Dutch elm disease reduced the numbers of trees considerably. At the same time the frequency of citizen complaints relating to trees rose dramatically and it was soon recognized that a carefully planned urban forestry programme was required.

In 1970 the first urban forester was hired by the City of Windsor from the graduate urban forestry programme which had been established at the University of Toronto (Jorgensen 1967). The management approaches developed and the current status of the urban forestry programme in Windsor will be discussed in this paper.

\section{The Urban Forest}

Climate. Windsor is noted for its mild winters (January mean daily minimum temperature $-6.7^{\circ} \mathrm{C}$ ), hot summers (July mean daily maximum temperature $29.4^{\circ} \mathrm{C}$ ), long growing season (170 days) and adequate precipitation throughout the year $(76.2$ $\mathrm{cm}$ ) with a likelihood of an extended dry period ( $80 \%$ chance of 7 or more dry days) in the summer and early fall (Brown et al. 1968). The winds are predominantly from the west and southwest and result in considerable particulate matter being carried from the Detroit, steel and utility complexes into Windsor. Ouellet and Sherk (1967) have classified the area as being within plant hardiness climatic zone 7A which is comparable to the coastal areas of British Columbia and is remarkable for the great diversity of tree and shrub species able to flourish.

Soils. The soils of Windsor are predominantly lacustrine clays with the western third of the city resting on sandy soils overlying a clay plain. Urban development has resulted in much of the topsoil being removed and the remaining sand and clay layers being largely disturbed parent materials.

Area. The urban forest, under the jurisdiction of the Parks Department, is located on 2000 ha of street right-of-ways and 660 ha of municipal parks (approximately $20 \%$ of a total 13200 ha municipal area). A closed canopy of mature trees is located on $1000 \mathrm{~km}$ of street right-of-ways averaging 20.1 $\mathrm{m}(66 \mathrm{ft}$.) in width.

Tree Population. Windsor has a diverse tree cover. The older sections of Windsor, including Sandwich (1800) and the "Ferry Community" established in 1846, contain silver maple (Acer saccharinum L.), black locust (Robinia pseudoacacia L.), Manitoba maple (Acer negundo L.), red or green ash (Fraxinus pennsylvanica Marsh.), Wych elm (Ulmus glabra Huds.), tree of heaven (Ailanthus altissima (Mill.) Swingle), horse-chestnut (Aesculus hippocastanum L.) and white mulberry Morus alba L.).

Old Walkerville, established in 1890 as the residential area for the Walker Distillery, formerly contained a magnificent white elm (Ulmus americana L.) cover which is now greatly reduced by Dutch elm disease. East Windsor, the residential area for the motor industry in 1920, contains silver maple and a remnant of white elms. The Town of Riverside, which developed in 1920 as the residential spill-over area of Windsor, features silver maple, cottonwood (Populus deltoides Bartr.) and Manitoba maple. Norway maple (Acer platanoides L). was established in South Walkerville (approximately 1940) when shade trees became generally available from the Ontario nursery industry.

South Windsor became the post-war area of residential expansion in 1950 and contains a wide variety of trees established by individual owners. 
Many of the same species found in the older Windsor sections were also planted in South Windsor along with varieties of crab apple (Malus cutivars), blue spruce (Picea pungens L.), cultivars of honey locust (Gleditsia triacanthos var, inermis), some remnant pin oak (Qeurcus palustris Muenchh.) and swamp white oak (Quercus bicolor Willd.).

Forest Glade, the latest subdivision, contains a diverse tree population of green ash, red maple cultivars (Acer rubrum L.), sugar maple (Acer saccharum Marsh.), red oak (Quercus rubra L.), honey locust cultivars together with some European species.

Over the years some magnificent woodlots have been incorporated into the urban community. Memorial Park, for example, contains the original oak cover of pin oak, black oak (Quercus velutina Lam.), swamp white oak and bur oak (Quercus macrocarpa Michx.) hybrids, shellbark hickory (Carya laciniosa (Michx. f. Loud.) and shagbark hickory (Carya ovata (Mill.) K. Koch.). Ojibway Park, once slated for residential development, contains a unique assemblage ( $44 \mathrm{ha}$ ) of tall grass prairie and associated plants (Burridge 1975).

\section{Management of the Urban Forest}

Objectives. It has been generally recognized that urban vegetation has considerable beneficial effects upon micro-climate and human comfort (Little and Noyes 1971). In the constantly changing man-made environment of the municipality medium and large-sized trees are providing a sense of stability, historic connection with past events, and a more human scale to the existing apartment complexes. Thus, the fundamental management goal of the Windsor parks department is the establishment and maintenance of a permanent canopy of healthy trees throughout the municipality. This is accomplished in the following ways:

1. the establishment and periodic review of optimal arboricultural standards and practices;

2. the planting of trees varying in species composition, age, size, shape and branch structure;

3 . the development of a disease and insect management system based on biological considerations minimizing chemical control;

4. the deployment of personnel, equipment and materials to obtain a balanced annual workload and an efficient use of budgetary funds;

5. the maintenance of healthy trees through periodic trimming and removal by both municipal employees and private contractors;

6. the utilization of wood and wood products;

7. the cultivation of good public relations;

8. the development of educational training programmes for employees as well as interpretive programmes for the general user of woodlots and natural areas.

Planting. Most municipalities in Ontario carry out the usual "bare-foot" planting of trees two to three metres in height. In this manner large numbers of street trees can be established inexpensively. However, combined losses through poor establishment and vandalism claim an estimated
$30 \%$ of annual tree plantings. This compares with a $40 \%$ loss experienced in Lansing. Michigan (Cool 1976). Balled and burlapped trees or treespade plantings provide alternatives to this approach. In Windsor acquisition of expensive balled stock and the slow procedure of underground utility line location for tree-spade plantings have limited these plantings to special areas.

A novel approach in Windsor has been to purchase trees of one to two metres in height and line them out on vacant municipal lands. The value of these trees doubles or quadruples in two to four years and the incoming stock is nursed, allowing damaged roots to recover before being replanted on streets. Also, a ready supply of trees is available for spring planting early in April. A variety of tree species is planted to ensure resistance to disease, insects and air pollutants.

Insects and Disease Control. Local outbreaks of insects and diseases, as illustrated by Turner et al. (1975), occur regularly or periodically in Windsor. A preventive spray program for all trees in the city is financially prohibitive and environmentally undesirable (Olkowski 1974). Minor infestations are not treated while serious infestations of a local nature are treated by using a portable sprayer mounted on an aerial tower. The application of high pressure water streams from a hydraulic sprayer was found to reduce aphid populations on lindens, maples and ash by approximately $85 \%$ in Berkeley, California. This technique was tried in Windsor in 1976 to combat aphid populations causing minor defoliation in Norway maples. The problem was alleviated to some degree but the overall effectivenss remained questionable. A real need exists in municipalities such as Windsor to determine levels of insects from month to month and to evaluate the effectiveness of various control methods.

Approximately 10,000 elms have been lost in Windsor since the initial outbreak of Dutch elm disease in 1957 despite a considerable effort to remove diseased trees. In 197536 elms in Jackson Park were injected using M.B.C. phosphate (Kondo et al. 1973) in an effort to arrest the disease locally. In 1976 a second area containing 220 elms was treated similarly. Initial results indicate that this method, supplemented with trunk spraying with methoxychlor (Gardiner 1975), has slowed the devastation of this disease to a mortality rate of about $2 \%$ on 900 elms remaining in Windsor.

Personnel and Equipment. The City of Windsor has been divided into ten districts. The trees in each district are surveyed to determine trim assignments, tree removals and new trees to be planted. If the work is to be done by a city crew a work order is issued. The Windsor Utilities Commission assists our crews by clearing branches touching the high voltage lines. The forestry crews utilize two aerial towers, one chipper truck, and a rope and saddle trim crew of six men. In the winter months two dump trucks and a tractor are used for the removal of trees. In the summer, an additional student crew injects elms.

When tree work is to be carried out by contract 
specifications are prepared. Contract tree trimming and removal as well as stump removal have proven to be less expensive than doing the work with city employees. Trimming specifications have been developed over the last seven years which are now in use by several other Ontario municipalities (Morsink 1976). This document treats legal and technical aspects relating to good arboricultural standards and practices.

The tree work record (Table 1) indicates that a large number of diseased elms were removed in 1965 , as compared with a relatively small number of large trees trimmed. In 1966, the year of annexation, the number of large trees trimmed increased by $100 \%$ in an effort to provide service to the new areas of Windsor. As a result, the removal of diseased elms fell behind and Dutch elm disease reached an unprecedented level with a mortality rate between 25 and $40 \%$ during the next few years. At this time calls for tree trims were in excess of the capability of our forestry crews and from 1969 to 1976 approximately 9,000 trees were trimmed successfully on contract. City forestry crews concentrated on removing the backlog of diseased elms and now are trimming an increasing number of large trees.

Due to the decimation of our elm cover and partly because of the low quality tree cover present in annexed areas, approximately 20,000 street trees have been established since 1968. As these small trees develop more time is spent on trimming and improvement of branching structure.

'In order to reduce costs wetting agents have been introduced in the watering of potted trees and flowers located in the main business districts (Burridge 1971).

Utilization. Logs from the forestry program were formerly disposed of at the municipal landfill. Starting in 1976 logs up to one metre in diameter have been auctioned to be split and sold as fire wood by commercial arboricultural firms. Some quality logs of black walnut (Juglans nigra L.) have been salvaged but the majority of logs are decayed silver maple and other hardwoods without commercial value. Diseased white elms are stlil disposed of through the landfill site by order of Council. This municipality has considered the use of various log and branch chippers to produce quality chips for the municipal sludge composting program. Such chipping equipment is used in the city of Detroit, Michigan, to dispose of diseased elms. Chips are then used to generate steam for the heating of two schools. In Flint, Michigan, similar chipping equipment has been in use for a number of years (Tapp 1974). In Windsor all chips produced from our trimming operation have been utilized on chip trails in Ojibway Park, the tree area and on some of the shrub beds.

Public Relations. The citizens of Windsor have shown a great interest in trees and support for the forestry programme. In $1976 \quad 1,800$ citizens requested information on trees, or work to be performed on trees, while another 2,000 called to report storm damage to trees from a severe ice storm which occurred in March of the same year.
Table 1 - Summary of tree trims and tree removals in Windsor, Ontario

\begin{tabular}{|c|c|c|c|c|}
\hline \multirow[b]{2}{*}{ Year } & \multicolumn{2}{|c|}{ Tree trims } & \multicolumn{2}{|c|}{ Removals } \\
\hline & large & small & elm & other \\
\hline $\begin{array}{l}1965 \ldots \ldots \\
1966 \ldots \ldots \\
1967 \ldots \ldots \\
1968 \ldots \ldots \\
1969 \ldots \ldots \\
1970 \ldots \ldots \\
1971 \ldots \ldots \\
1972 \ldots \ldots \\
1973 \ldots \ldots \\
1974 \ldots \ldots \\
1975 \ldots \ldots \\
1976 \ldots \ldots \\
\end{array}$ & $\begin{array}{r}674 \\
1641 \\
685 \\
1665 \\
1805 \\
2612 \\
5091 \\
3827 \\
3863 \\
4845 \\
3242 \\
4375\end{array}$ & $\begin{array}{r}786 \\
3681 \\
3342 \\
5285 \\
3654\end{array}$ & $\begin{array}{r}1872 \\
866 \\
1276 \\
1413 \\
199 \\
408 \\
167 \\
112 \\
141 \\
40 \\
70 \\
32\end{array}$ & $\begin{array}{r}70 \\
87 \\
149 \\
308 \\
217 \\
324 \\
145 \\
443 \\
491 \\
531 \\
337 \\
194\end{array}$ \\
\hline
\end{tabular}

Some citizens have expressed their hostility towards the three in front of their home when roots penetrate sewers and leaves and fruits affect the cleanliness of the garden.

The parks department through its forestry programme has direct contact with about one or two per cent of the population annually. To aid in the process of good public relations (Tate 1976), a card index for individual houses was initiated in 1966 noting species statistics and work performed. All calls are further investigated by the city forester and usually resolved to the mutual satisfaction of citizen and municipality. In 1971 Arbor day was expanded to Arbor month in Windsor and the continuation of this programme has resulted in a heightened awareness among citizens of the many values of trees in the urban environment (Budridge 1972).

The desire by the Windsor parks department to protect municipal trees from various injurious effects, as described by Michna (1975), has led to the drafting of a municipal tree by-law. This bylaw, when approved by city council, will enable standards for construction near trees, as outlined by Barker (1975), to be well publicized.

\section{Discussion}

Rasleigh (1962), noted in a study of Canadian cities that a district is improved more by the attention to its vegetation than by adding to the value of the houses. The more prestigious residential areas invariably featured treed open space. The Toronto Real Estate Board (1973) estimated that the value of urban vegetation contributed at least $10 \%$ to the real estate value of residences. The urban forest contributes much to create a habitable environment and has resulted in many pleas to "plant a tree and save a city" (McGuire 1975). Thus, many communities in Canada should adopt an urban forestry programme, even though many hurdles may have to be overcome in establishing such a programme (Weidhaas 1976).

An important task simultaneous with the initial survey of the existing tree population is the removal of dead branches, diseased and dead trees. The development of a systematic tree planting and maintenance program would follow. A card index. 
system should be initiated to have available an ongoing record of work performed. The transformation of the card index system in Windsor to a more sophisticated inventory system as outlined by Bassett et al. (1975) and Johannsen (1975), would be a logical further development. A computer based information and management system is ideally suited for handling a large base of data from which the forester could aggregate general as well as specific levels of information.

In many municipalities, there exists a need for the planting of a greater variety of tree species. A diversity in species and their placement does much to soften the stark linearity of streets. A wide choice in the variety of species has become the cornerstone in the development of a disease management system in Windsor, since preventive spray programs are financially prohibitive and environmentally undesirable. Another need exists in evaluating at the municipal level the effect of control measures on insect and disease populations. The mild climate of Windsor has made possible the acquisition of a great variety of tree species. The majority of Canadian communities, however, are experiencing difficulties in obtaining such a diversity due to climatic limitations of many species of trees. Much work remains to be carried out in the selection of suitable native species (Morsink and Jorgensen 1974).

In conclusion, Windsor has been fortunate in having a council which recognized the need for an urban forestry programme a number of years ago.

\section{References}

Barker, P. A. 1975. Ordinance control of street trees. J. Arboriculture 1 (11): 212-215.

Bassett, J. R. and W. C. Lawrence. 1975. Status of street tree inventories in the U.S. J. Arboriculture 1(3):48-52.

Brown, D. M., G. A. McKay and L. J. Chapman. 1968. The climate of southern Ontario. Canada, Dept. of Transport, Met. Branch Clim. Studies No. 5.
Burridge, L. O. W. 1971. Wetting agents and the watering of trees. Ont. Shade Tree Council Newsletter 4(3):4-5.

1972. Windsor's maxi arbor day. Can. Nurseryman $9(3): 13$.

1975. Unique Prairie in unexpected location. Recreation Canada. 33(3):16-17.

Cool, R. A. 1976. Tree spade vs. bare foot planting. J. Arboriculture 2(5):92-95.

Gardiner, L. F. 1975. Control of Dutch elm disease. Can. For. Res. Newsletter 5(4):5-6.

Johannsen, H. J. 1975. Municipal tree survey and urban tree inventory. J. Arboriculture 1(4):71-74.

Jorgensen, E. 1967. Urban forestry: Some problems and proposals. Fac. For. Univ., Toronto, Ontario.

1974. Towards an urban forestry concept. Can. For. Serv., Environment Canada.

Kondo, E. S., D. N. Roy and E. Jorgensen. 1973. Salts of methyl-2-benzimidazole carbamate (MBC) an assessment of their potential in Dutch elm disease control. Can. J. For. Res. 3(4):548-555.

Little, S and J. H. Noyes, Eds. 1971. Trees and forests in an urbanizing environment. Coop. Ext. Serv., Univ. Massachusetts, Monograph 17.

McGuire, J. R. 1975. Plant a tree and save a city. J. Arboriculture 1(11):208-211.

Michna, F. R. 1975. Trees should have standing. J. Arboriculture $1(4): 78-80$.

Morsink, W. A. G. 1976. Tree contracting in Windsor. Yearbook Ont. Shade Tree Council, 1976.

and E. Jorgensen 1974. Propagation and selection of sugar maple (Acer saccharum Marsh.) in Ontario. Ont. Min. Nat. Res.

Olkowski, W. 1974. Managing an ecosystem insect program. Grounds Maintenance 20(2):41-75.

Ouellet, C. E. and L. C. Sherk. 1967. Woody ornamental plant zonation: suitability map for the probable winter survival of ornamental shrubs and trees. Can. J. Plant Sci. 47(4): 351-358.

Rasleigh, S. T. 1962. Observations on Canadian cities. J. Plann. Canada 3(2):60-77.

Tapp, T. 1974. What to do with waste wood. Yearbook, Ont. Shade Tree Council, 1974.

Tate, R. L. 1976. Public relations in urban forestry. J. Arboriculture 2(9):170-172.

Toronto Real Estate Board 1973. Listings, vol. 29:13-17.

Turner, K. B., C. S. Kirby and B. W. Dance. 1975. Common pests of ornamental trees and shrubs. Ont. Min. Nat. Res. Publ. P. C. 3.

Weidhaas, J. A. 1976. Goals and hurdles for shade tree programs. J. Arboriculture 2(9):176-180. 